\title{
Quality of Minimally Processed Beet Roots Stored in Different Temperatures
}

\author{
Maria Carolina Dario Vitti ${ }^{1}$, Liane Kazuko Yamamoto ${ }^{1}$, Fabiana Fumi Sasaki ${ }^{1}$, Juan \\ Saavedra del Aguila ${ }^{1}$, Ricardo Alfredo Kluge ${ }^{1 *}$ and Angelo Pedro Jacomino ${ }^{2}$ \\ ${ }^{1}$ Departamento de Ciências Biológicas, Escola Superior de Agricultura "Luiz de Queiroz", Universidade \\ de São Paulo, C.P. 9, 13418-900, Piracicaba, SP, Brasil; ${ }^{2}$ Departamento de Produção Vegetal, Escola \\ Superior de Agricultura “Luiz de Queiroz”, Universidade de São Paulo, São Paulo - SP - Brasil
}

\begin{abstract}
The present work was carried out with the objective to determine the effect of different storage temperature on the quality of beet root minimally processed. Respiratory activity and mass loss were higher in the storage at $15^{\circ} \mathrm{C}$. No significant differences in color, total soluble solids, betacyanin and betaxanthin were observed among treatments. Based on the results obtained, the storage at $0^{\circ} \mathrm{C}$ was recommended to storage beet root minimally processed and that 10 and $15^{\circ} \mathrm{C}$ drastically reduced the quality of minimally processed beet roots during storage.
\end{abstract}

Key words: Beta vulgaris L., fresh-cut, betalains, respiratory rate

\section{INTRODUCTION}

Beet is a root vegetable of the Chenopodiaceae family whose edible part is its tuberous root. Its purple-red color is due to the presence of betalain pigments. These pigments are similar to anthocyanins and flavonoids, which were wrongly termed in the old literature as anthocyanins containing nitrogen. Betalains are water-soluble pigments and are found only in ten families of the Centrospermae group and are divided into two classes: red betacyanin and yellow betaxanthin, which provide beet roots with their typical color (Fenena, 1995). Besides, these pigments often exhibit antioxidant activity and potential health benefits of vegetables (Kanner et al., 2001).

Minimal processing (fresh-cut) comprises selection, washing, peeling and cutting procedures that are aimed at producing a product that is fresh and convenient to prepare and consume (Burns, 1995). Minimally processed fruits and vegetables are more perishable than their whole counterparts, due to undergoing severe physical stresses especially during peeling and cutting procedures. Cutting, associated with high storage temperatures, leads to an increase in the respiratory rate, with an increase in the activity of enzymes involved in specific reactions (Chitarra, 1998).

Temperature control is the most common and important technology to minimize the effects of cutting in fruits and vegetables (Brecht, 1995). Whole and sliced carrots kept at 0 and $10^{\circ} \mathrm{C}$ showed the importance of low temperatures for the reduction of the respiratory process, and consequently the metabolism in vegetables. Whole carrots produced 3.7 and $5.2 \mathrm{mg} \mathrm{CO}_{2} \mathrm{~kg}^{-1} \mathrm{~h}^{-1}$ at 0 and $10^{\circ} \mathrm{C}$, respectively, which represented an increase of $40.54 \%$ in respiration at $10^{\circ} \mathrm{C}$, and

\footnotetext{
*Author for correspondence
} 
carrot slices produced 6.0 and $10.9 \mathrm{mg} \mathrm{CO}_{2} \mathrm{~kg}^{-1} \mathrm{~h}^{-1}$ at 0 and $10^{\circ} \mathrm{C}$, respectively, which represented an increase of $66.67 \%$ in respiration at $10^{\circ} \mathrm{C}$. When comparing the respiratory rates of whole or slices carrots stored to the different temperatures, slices carrots showed increase of $62.2 \%$ and $92.3 \%$ in respiration rate if compared to whole carrots at $0^{\circ} \mathrm{C}$ and $10^{\circ} \mathrm{C}$, respectively (Cantwell, 1992).

Beet root is a vegetable that has expanded its presence in the minimally processed food market. However, high quality loss has been observed due to discoloration of root surfaces and high water loss of minimally processed roots. Washing and rinsing, carried out after the product is cut, have contributed to the loss of betalain and betaxanthin pigments.

In view of the factors mentioned above, the economic importance of beet and the lack of information in the literature about the minimally processed use of this vegetable focused on the degradation of pigments, respiratory rate and mass losses, the present work was aimed at determining the storage temperature that best promote quality maintenance in minimally processed beet.

\section{MATERIAL AND METHODS}

Tuberous roots of "Early Wonder" beets were obtained from a beet crop in Piracicaba, SP, Brazil. The roots were selected by firmness and absence of mechanic injuries or fungal infection. Roots were pre-washed in running water to remove impurities and stored in cold room at $10^{\circ} \mathrm{C}$ before being minimally processed.

The product was mechanically peeled in an industrial peeler with an abrasive disc. After this, beets were immersed in cold water $\left(5^{\circ} \mathrm{C}\right)$ for 2 minutes to reduce the heat from the field and, consequently, reduce the metabolic activity. Next, roots were shredded to little pieces in an industrial processor equipped with a $2 \mathrm{~mm}$-thick disc and the material was sanitized with active chlorine $(200 \mathrm{mg}$ $\mathrm{L}^{-1}$ ) for 6 minutes to reduce risks of contamination, rinsed with active chlorine $\left(3 \mathrm{mg} \mathrm{L}^{-1}\right)$ for 1 minute to remove the excess chlorine and, finally, centrifuged at $800 \times \mathrm{x}$ for 1 minute to remove the excess water.

All treatments were placed in expanded polystyrene trays $(180 \mathrm{~g}$ net, $14 \times 20 \mathrm{~cm})$, wrapped in 14-micra thick polyvinyl chloride (PVC) films and stored at $0 \pm 1,5 \pm 1,10 \pm 1$ or $15 \pm 1^{\circ} \mathrm{C}$ and
$85 \pm 5 \%$ RH for 10 days. Evaluations were carried out each 2 days

The variables analyzed were: a) respiratory rate: $150 \mathrm{~g}$ of minimally processed beet were placed in $600 \mathrm{~mL}$ glass flasks and hermetically sealed for 1 hour at $5^{\circ} \mathrm{C}$. A silicone septum was fitted in the flasks lids to allow the collection of a $2 \mathrm{~mL}$ aliquot from the flasks internal atmosphere and readings were carried out in a gas analyzer. Results in \% $\mathrm{CO}_{2}$ were used in the calculation of the respiratory rate, which considered the flasks volume, the beet mass and the time the flask remained closed; b) total soluble solids amount: measured by direct reading of a drop of root material centrifuged in a household centrifuge. Results were expressed in ${ }^{\circ}$ Brix; c) color: determined with a colorimeter (Minolta) by determining $\mathrm{L}, \mathrm{a}^{*}$ and $\mathrm{b}^{*}$ values and calculating the color index (CI) through the equation $\mathrm{CI}=1000 \mathrm{xa} * / \mathrm{Lxb}^{*}$ (Mazzuz, 1996). Readings were carried out directly on the minimally processed product; d) betacyanin and betaxanthin amounts: the methodology used was an adaptation from Nilson (1970). Two grams of previously frozen samples were macerated in $5 \mathrm{~mL}$ distilled water. The solution was placed into tubes and centrifuged at $15,000 \mathrm{rpm}$ and $4^{\circ} \mathrm{C}$ during 40 minutes. One $\mathrm{mL}$ of the overflowing liquid and $24 \mathrm{~mL}$ of distilled water were homogenized in a test tube. Readings were carried out at $476 \mathrm{~nm}$, $538 \mathrm{~nm}$ and $600 \mathrm{~nm}$. Values of betacyanin and betaxanthin amounts were obtained through the equation $\mathrm{x}=1.095(\mathrm{a}-\mathrm{c}), \mathrm{y}=\mathrm{b}-\mathrm{z}-\mathrm{x} / 3.1$ and $\mathrm{z}=\mathrm{a}-\mathrm{x}$, where: $a=$ sample reading $(538 \mathrm{~nm}) ; \mathrm{b}=$ sample reading $(476 \mathrm{~nm}) ; \mathrm{c}=$ sample reading $(600 \mathrm{~nm}) ; \mathrm{x}=$ betacyanin absorption; $y=$ betaxanthin absorption; $\mathrm{z}=$ impurities absorption; e) sensory evaluation (general appearance): carried out by a team of 5 fully trained evaluators using an score scale adapted from Peryam and Girarddot (1952), where $9=$ excellent; $7=$ good; $5=$ regular; $3=$ bad; $1=$ very bad. The scores corresponded to $9=$ beet appearing fresh and absence of white blush; $7=$ beet looking fresh, but showing light whitening; $5=$ beet looking fairly fresh and showing moderate white blush; $3=$ beet lacking freshness and showing great white blush; $1=$ totally dehydrated and white blush beet. Score 5 was considered to be the commercialization threshold; f) mass loss: measured by direct weighing with results expressed in \%.

A completely randomized factorial $4 \times 6$ design (4 storage temperatures and 6 evaluation periods) with 4 replicates of approximately $150 \mathrm{~g}$ of 
minimally processed roots each was used. Results from physicochemical analyses were submitted to a standard deviation analysis, in which differences between two treatments exceeding two standard deviations were considered significant $(\mathrm{P} \leq 0.05)$ (Moretti et al., 2002). Before the sensorial analysis, the homogeneity of variances was tested through the Hartley test. Once the heterogeneity of variances was not verified at $\alpha=0.05$, an analysis of variance ( $F$ test) and a comparison of means by Tukey test at $5 \%$ probability were carried out.

\section{RESULTS AND DISCUSSION}

The respiratory activity has varied significantly as a function of the storage temperature (Fig. 1). No respiratory activity was observed at $0^{\circ} \mathrm{C}$. According to Van't Hoff's law, for each increase of $10^{\circ} \mathrm{C}$ in temperature there is a twofold or threefold increase in the speed of metabolic reactions, including respiration (Moretti et al., 2000). This could be proved by observing that the respiratory rate of beets stored at $15^{\circ} \mathrm{C}$ was approximately twice higher to the verified in beets stored at $5^{\circ} \mathrm{C}$.

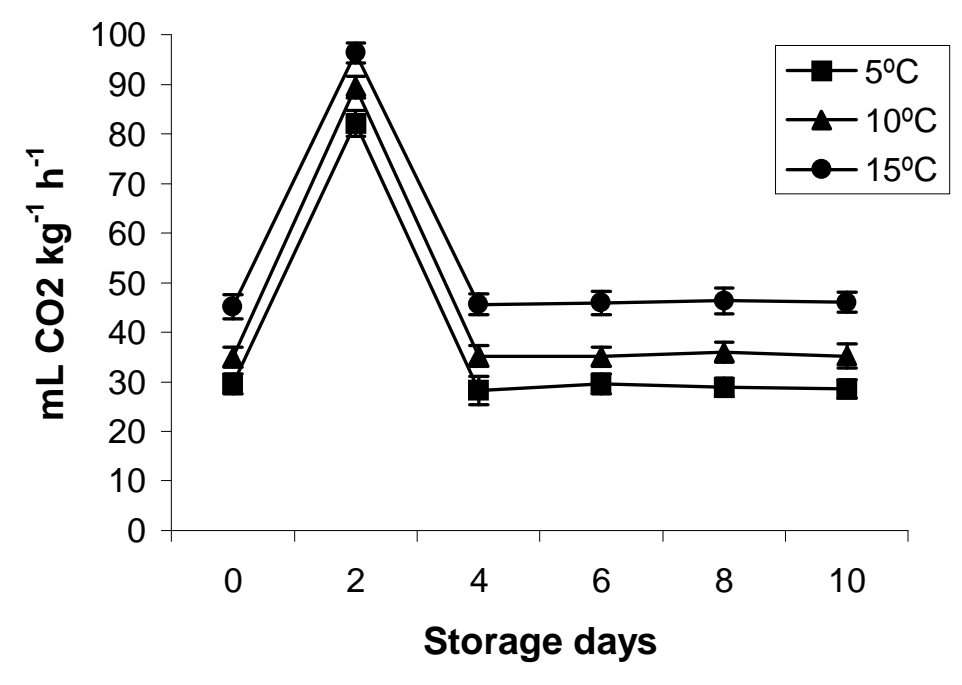

Figure 1 - Respiratory rate of minimally processed beet roots stored in different temperatures. Vertical lines represent standard deviations from mean.

There was a peak in the respiratory activity on the second day of storage (values from 80 to $100 \mathrm{~mL}$ $\left.\mathrm{CO}_{2} \mathrm{~kg}^{-1} \mathrm{~h}^{-1}\right)$. From the $4^{\text {th }}$, day respiratory rate decreased and stabilized between 25 and $40 \mathrm{~mL}$ $\mathrm{CO}_{2} \mathrm{~kg}^{-1} \mathrm{~h}^{-1}$. Osornio and Chaves (1998) observed similar results for the respiratory behavior in grated beet roots. The respiratory peak observed in the beginning of cold storage was probably due to the stress caused by cutting, which promoted loss of cellular compartmentalization and consequenting greater contact between substrates from respiratory metabolism and enzymatic complexes. The subsequent reduction in the respiratory rate from the $4^{\text {th }}$ day was probably due to the self-regulation of the tissue respiratory activity caused by the great production of ATP (Purvis, 1997). It was also possible that such reduction in the respiratory rate happened because respiratory substrates stop reacting with the enzymes of the cells present on the cut surface. Therefore, the respiratory rate observed from the $4^{\text {th }}$ day was probably caused by cells lying below the surface injured by the cut.

The mechanical damage caused by cutting or peeling is one of the largest obstacles to storage of minimally processed commodities, which show respiratory rates 3 to 5 times higher than intact organs (Chitarra, 1998). Thus, keeping products at low temperatures from processing through commercialization becomes indispensable for 
reducing respiration and preserving quality and shelf life of the preprocessed product.

Total soluble solids amounts varied little during refrigerated storage, with values ranging between 4 and $5{ }^{\circ}$ Brix (Fig. 2).

A gradual decrease in the color index (CI) throughout the storage period was observed, with no significant differences among the temperatures evaluated (Fig. 3). According to Mazzuz (1996), CI values range from -20 to +20 , and the more positive the value the greater the intensity of the roots red color.

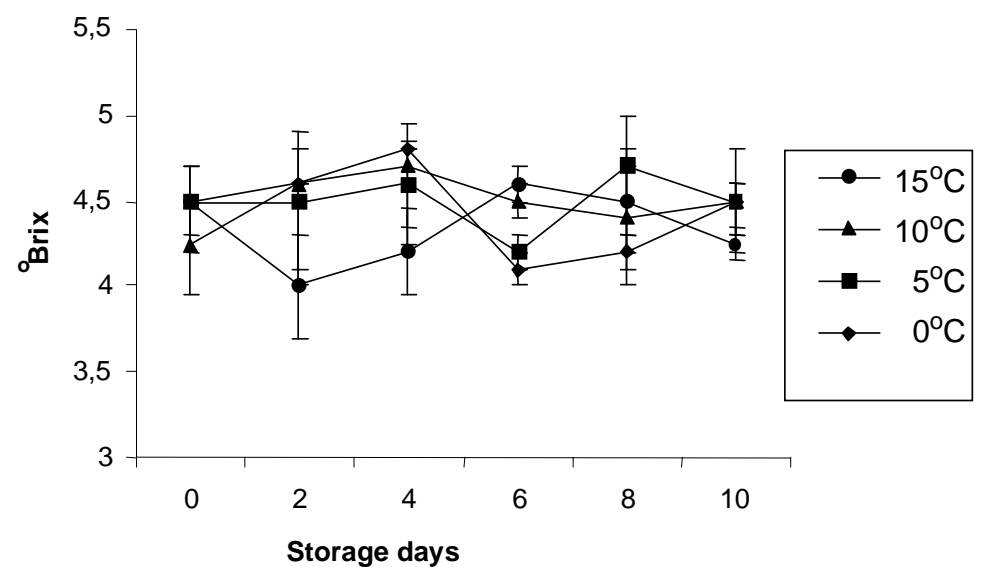

Figure 2 - Total soluble solid ( ${ }^{\circ}$ Brix) of minimally processed beets at different storage temperatures. Vertical lines represent standard deviations from mean

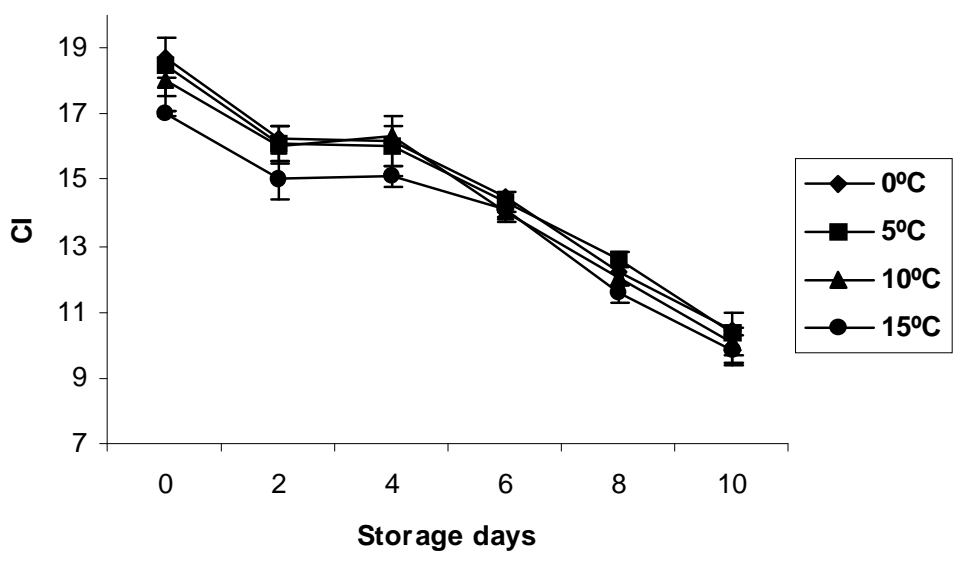

Figure 3 - Color index $(\mathrm{CI})$ in minimally processed beet roots stored in different temperatures. Vertical lines represent standard deviations from mean. 
a
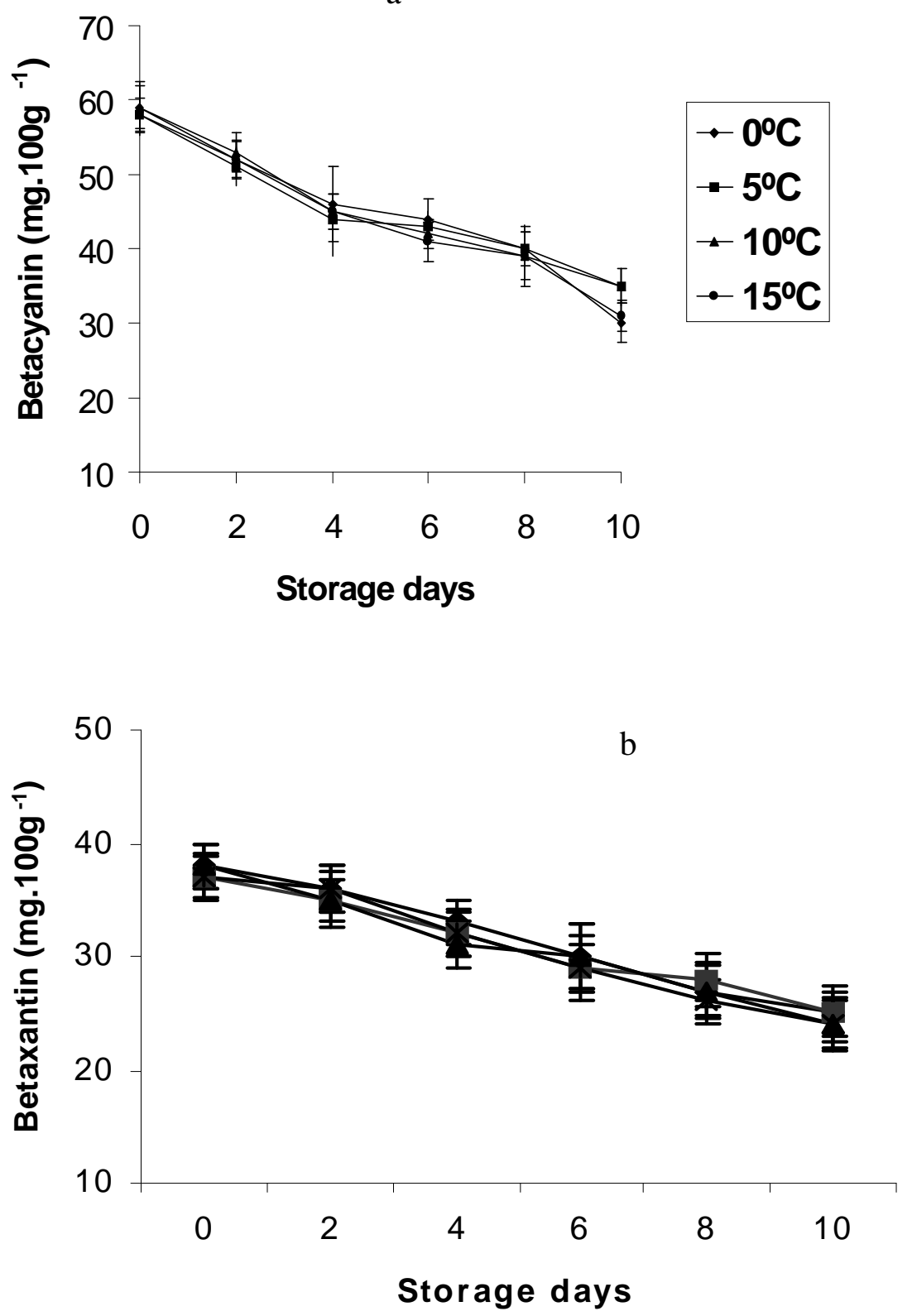

Therefore, increases in CI values during storage meant loss of intensity of the typical beet red color. Similarly, there was a decrease in betacyanin and betaxanthin amounts along the experiment (Fig. $4 a$ and $b$ ).

There are few studies in relation to quantification of betalains in beet roots. According to Nilson (1973), betaxanthin amounts in different undamaged beet cultivars were 20-60, 60-130 and $60-140 \mathrm{mg}^{1} 100 \mathrm{~g}^{-1}$ of beet, while betacyanin amounts were 45-85, 130-200 and 130-210mg
$100 \mathrm{~g}^{-1}$ of beet for the varieties Banco WW, Boltardy and Rubra, respectively. Sapers and Hornstein (1979) founded high differences in betacyanin and betaxanthin amounts among the varieties of table beet. Differences within cultivars were also observed with some cultivars being more variable than others. Osornio and Chaves (1998) observed decreases in betalain amounts of around $40-50 \%$ in grated beet after 7 days of refrigerated storage. 
Betalain pigments are more soluble in water than in alcohol (Nilson, 1970). As for minimally processed beet, sanitization and rinsing favor larger pigment losses due to the exposure of the root surfaces to water. Recently, Vitti (2003) demonstrated that dipping fresh-cut beet roots in a solution of citric acid reduced significantly the losses of betalains pigments.

The analysis of the general appearance indicated that minimally processed beets stored at $0^{\circ} \mathrm{C}$ showed quality standards varying from good to very good up to 10 days of storage (Table 1). Beets stored at $5^{\circ} \mathrm{C}$ showed maximum commercialization time of 6 days, while those stored at $10^{\circ} \mathrm{C}$ and $15^{\circ} \mathrm{C}$ showed commercialization time of only 4 days.

The whitening tissue that often occurred over the surface of minimally processed carrots, called "white blush", gave the product a stale and unattractive appearance, similar to what happened with beet root minimally processed in this work. White blush could be the result of dehydration of superficial cells due to damages during processing (Tatsumi et al., 1993; Avena-Bustillos et al., 1994) or it could be due to the formation of lignin on the cut surface (Bolin and Huxsoll, 1991). White blush process could also be caused by the combination of two processes, dehydration and formation of lignin (Cisneros-Zevallos et al., 1995).

Table 1- General appearance of beets minimally processed stored at different temperatures ${ }^{1}$.

\begin{tabular}{|c|c|c|c|c|c|c|}
\hline \multirow{2}{*}{$\begin{array}{c}\text { Storage } \\
\text { Temperature }\end{array}$} & \multicolumn{6}{|c|}{ Storage days } \\
\hline & $\mathbf{0}$ & 2 & 4 & 6 & 8 & 10 \\
\hline & \multicolumn{6}{|c|}{ Scores $^{2}$} \\
\hline $0^{0} \mathrm{C}$ & $9 a$ & $9 a$ & $9^{a}$ & $9^{a}$ & $7 \mathrm{a}$ & $6 a$ \\
\hline $5^{0} \mathrm{C}$ & $9 \mathrm{a}$ & $9 \mathrm{a}$ & $8^{a}$ & $5 b$ & $3 b$ & $3 b$ \\
\hline $10^{\circ} \mathrm{C}$ & $9 \mathrm{a}$ & $7 b$ & $5 b$ & $3 b$ & $3 b$ & $1 \mathrm{~b}$ \\
\hline $15^{0} \mathrm{C}$ & $9 \mathrm{a}$ & $7,5 b$ & $5 b$ & $3 b$ & $3 b$ & $1 b$ \\
\hline Means & $\begin{array}{c}9,0 \\
\mathbf{A}\end{array}$ & $\begin{array}{c}8,13 \\
\text { A }\end{array}$ & $\begin{array}{c}6,75 \\
\text { B }\end{array}$ & $\begin{array}{c}5,13 \\
C\end{array}$ & $\begin{array}{c}4,00 \\
D\end{array}$ & $\begin{array}{c}2,75 \\
\text { E }\end{array}$ \\
\hline
\end{tabular}

${ }^{1}$ Means followed by the same small letter in the column and the same capital letter in the row did not differ significantly between them by Tukey test at $5 \%$ probability. ${ }^{2}$ Scores: $9=$ excellent; $7=$ very good; $5=$ regular, commercialization limit; $3=$ average, consumption limit; 1 = poor, uneatable

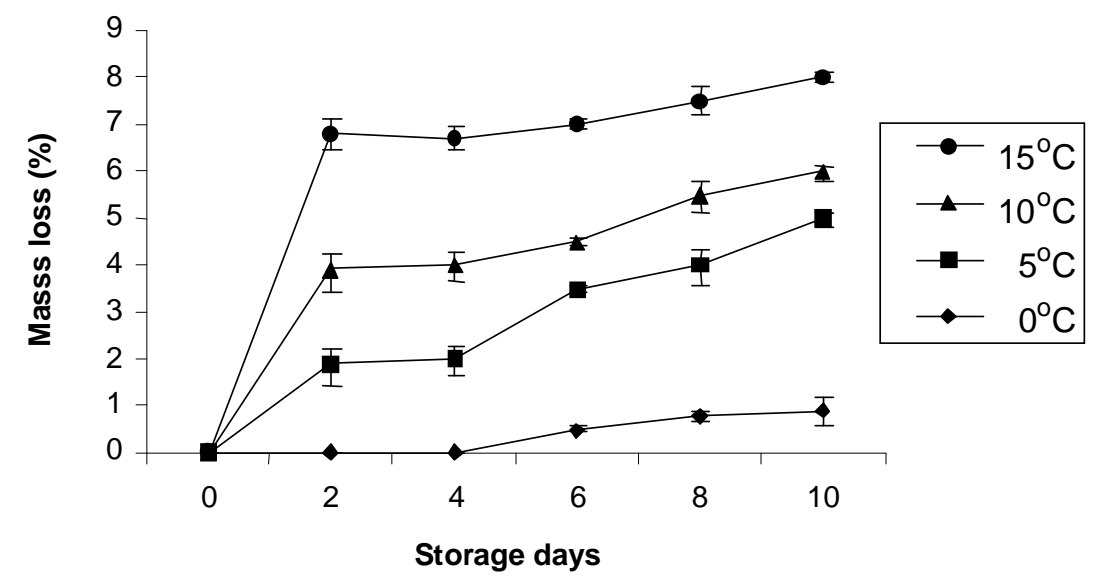

Figure 5 - Mass loss in minimally processed beets stored at different storage temperatures. Vertical lines represent standard deviations from mean. 
Dehydration was evidenced by a reversible color change that increases with increased in water loss, while the activation of phenolic metabolism and the lignin production resulted in an irreversible color change (Izumi et al., 1996).

In this study, the main depreciative factors to the appearance of minimally processed beets were color loss and dehydration. It was observed that the higher the storage temperature, the higher was the dehydration (Fig. 5).

Although a PVC film offers the minimally processed product a barrier against water loss, the storage temperature plays a fundamental role on the deficit of pressure vapor (DPV) between internal tissues of the product and the environment (Gorris and Peppelenbos, 1992). Thus, considering a fixed relative humidity, the higher the temperature the greater would be the DPV, which causes more transpiration.

Results showed that there was a reduction in the color index (CI) and in the betacyanin and betaxanthin amounts during storage, although no significant differences were observed in any treatment. The reduction in color intensity was apparently due to alterations in the amounts of pigments, which were gradually lost during cold storage. Dehydration and white blush of roots, which reduced the intensity of red color on the cut surface, were observed in all the treatments during the experiment. It was also observed that the higher the storage temperature, the greater was the dehydration and white blush. Significant differences were observed in the respiratory rate and in the mass loss along the days of storage. Therefore, it could be concluded that the temperature influenced the storage of minimally processed beet roots, and that it was possible to keep the product for 10 days at $0^{\circ} \mathrm{C}$. It could also be inferred that temperatures of 10 and $15^{\circ} \mathrm{C}$ drastically reduced the quality of minimally processed beet roots during storage.

\section{ACKNOWLEDGEMENTS}

The authors thank to "FAPESP -Fundação de Amparo à Pesquisa do Estado de São Paulo", for providing financial assistance for this work.

\section{RESUMO}

O objetivo deste trabalho foi avaliar a temperatura de armazenamento que proporcione melhor manutenção da qualidade de beterrabas minimamente processadas. As raízes foram cortadas em retalhos de $2 \mathrm{~mm}$ de espessura. Após o preparo, foram acondicionadas em bandejas de poliestireno expandido e armazenadas a $0 \pm 1,5 \pm 1$, $10 \pm 1$ e $15 \pm 1^{\circ} \mathrm{C}$ durante 10 dias. A cada 2 dias foram avaliados a taxa respiratória, o teor de sólidos solúveis totais, a coloração, os teores de betacianina e de betaxantina, a aparência global e a perda de massa. A atividade respiratória e a perda de massa foram mais acentuadas durante $o$ armazenamento $15^{\circ} \mathrm{C}$. Não houve diferença significativa entre os tratamentos em relação à coloração, o teor de sólidos solúveis totais e os teores de betacianina e betaxantina. Pelos resultados obtidos, conclui-se que beterraba minimamente processada mantém boa qualidade para consumo por até 10 dias de armazenamento a $0^{\circ} \mathrm{C}$ e que temperaturas de 10 e $15^{\circ} \mathrm{C}$ reduzem drasticamente a sua qualidade durante $\mathrm{o}$ armazenamento.

\section{REFERENCES}

Avena-Bustillos, R. J.; Cisneros-Zevallos, L. A.; Krochta, J. M. and Saltveit, M. E. (1994), Application of casein-lipid edible film emulsions to reduce white bush on minimally processed carrots. Postharvest Biology and Technology, 4, 319-329.

Bolin, H. R. and Huxsoll, C. C. (1989), Storage stability of minimally processed fruit. Journal of Food Processing and Preservation, 13, 281-292.

Brecht, J. K. (1995), Physiology of ligthy processed fruits and vegetables. HortScience, 30, 18-22.

Burns, J. L. (1995), Lightly processed fruits and vegetables: Introduction to the Colloquium. HortScience, 30, 14-17.

Cantwell, M. (1992), Postharvest handling systems: minimally processed fruits and vegetables. In: Kader, A. A. Postharvest technology of horticultural crops. $2^{\text {nd }}$ ed. Davis : University of California. pp. 277-281.

Chitarra, M. I. F. (1998), Processamento mínimo de frutos e hortaliças. Viçosa : Centro de Produções Técnicas.

Cisneros-Zevallos, L.; Salveit, M. E. and Krochta, J. M. (1995), Mechanism of surface white discoloration of peeled carrots during storage. Journal of Food Science, 60, 320-323.

Fenena, O. R. (1995), Quimica de los alimentos. 2. ed. Zaragoza : Acribia. 
Gorris, L. G. M. and Peppelenbos, H. W. (1992), Modified atmosphere and vacuum packaging to extend the shelf life of respiring food products. HortTechnology, 2, 303-309.

Izumi, H.; Watada, A. E.; Ko, N. P. and Douglas, W. (1996), Controlled atmosphere storage of carrots slices, sticks and shreds. Postharvest Biology and Technology, 9,165-172.

Kanner, J.; Harel, S. and Granit, R. (2001), Betalains: a new class of dietary cationized antioxidants. Journal of Agricultural and Food Chemistry, 49, 5178-5185.

Mazzuz, C. F. (1996), Calidad de frutos cítricos: manual para sugestion desde la recoleccion hasta la expedicion. Barcelona : Edicionas de Horticultura.

Moretti, C. L. and Sargent, S. A. (2000), Alteração de aroma e sabor em frutos de tomate com desordem fisiológica causada por impacto. Scientia Agricola, 57, 385-388.

Moretti, C. L.; Marouelli, W. A. and Silva, W. L. C. (2002), Respiratory activity and browning of minimally processed sweet potatoes. Horticultura Brasileira, 20, 497-500.

Nilson, T. (1970), Studies into the pigments in beetroot (Beta vulgaris L. ssp. vulgaris var. rubra L.). Lantbrukhogskolans Annaler, 36, 179-219.

Nilson, T. (1973), The pigment content in beetroot with regard to cultivar, growth, development and growing conditions. Swedish Journal of Agriculture Research, 3, 187-200.

Osornio, M. M. L. and Chaves, A. R. (1998), Quality changes in stored raw grated beetroots as affected by temperature and packaging film. Journal of Food Science, 63, 270-330.

Peryam, D. R. and Girarddot, N. F. (1952), Advanced taste method. Food Engeneiring, 24, 58-61.

Purvis, A. C. (1997), The role of adaptive enzymes in carbohydrates oxidation by stressed and senescing plant tissues. HortScience, 32, 1165-1168.

Sapers, M. G. and Hornstein, J. S. (1979), Varietal differences in colorant properties and stability of red beet pigments. Journal of Food Science, 44, 1245.

Tatsumi, Y.; Watada, A. E. and Ling, P. P. (1993), Sodium chlorine treatment or waterjet slicing effects on white tissue development on carrot sticks. Journal of Food Science, 58, 1390-1392.

Vitti, M. C. D. (2003), Aspectos fisiológicos, bioquímicos e microbiológicos em beterrabas minimamente processada. Dissertação (Mestrado), Escola Superior de Agricultura "Luiz de Queiroz", Universidade de São Paulo, Piracicaba, SP. 